\title{
Loneliness and Displacement: A Postmodern Geocritical Reading of Jack London's "To Build A
}

Fire"

\author{
Amany Abdullah Abdel-Aziz Eldiasty \\ Lecturer of English Literature \\ Faculty of Arts \\ Damietta University
}

\section{Abstract}

Within the theoretical framework of geocriticism, this paper examines the physical setting in London's "To Build A Fire" through defining its fictional and real spaces. It investigates the relationship between the physical space of nature and the mental space of the main protagonist. Though a spatio-temporal analysis is followed here as the method of research, the researcher refutes the essential inseparability of time and space, arguing that a spatial perspective predominates a postmodern society fretting from anxiety, loneliness, 
fragmentation, detachment, alienation and displacement. The postmodern geocritical approach is applied to Jack London's "To Build A Fire" as this short story discusses elements which are germane to geocritical studies such as geographical boundaries, transgression, space, place, body, movements, life and death. Such elements are brought together within the journey motif, a widespread spatial schema, which dominates the course of the story. Not only does London use the journey as the traditional symbol of a quest, but he also employs it to structure his story. Though critical approaches tend to investigate or evaluate specific aspects in literature, they ignore the role of space which works both as part of the setting and as an effective and interactive element in the development of action in any literary work. The paper deduces London's disillusionment of the socio-economic changes that take place in America. London's geographic factors in "To Build A Fire" reflect the dominantly vanishing social economic changes of the place it is set in.

\section{Key Words:}

Geocriticism, postmodernism, space, displacement, journey, Jack London

$$
\begin{aligned}
& \text { الوحدة والتشريد: قراعةتقديةجغرافية لما بعد الحداثة لقصة جاك لندن } \\
& \text { "لكي توقد ناراً" }
\end{aligned}
$$

من خلال الإطار النظري لمدخل النقا الأدبي الجغرافي تبحث هذه الورقة الزمكانية

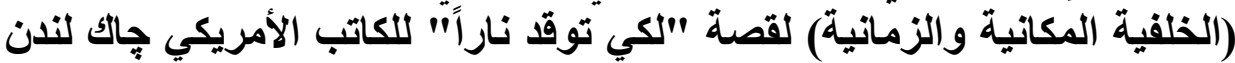

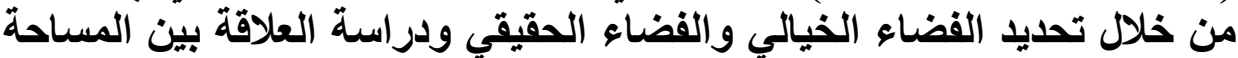

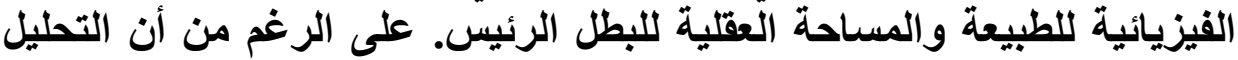

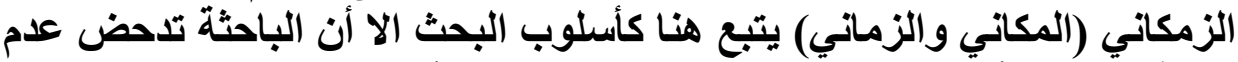

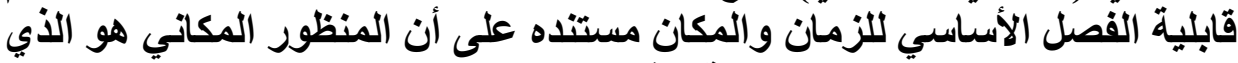

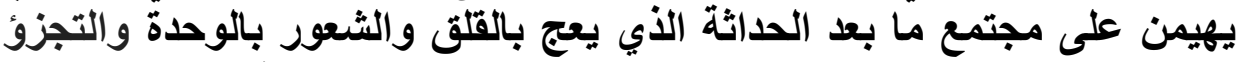

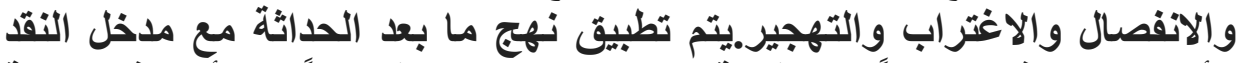

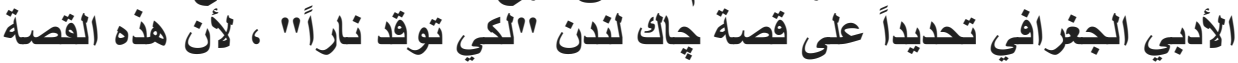

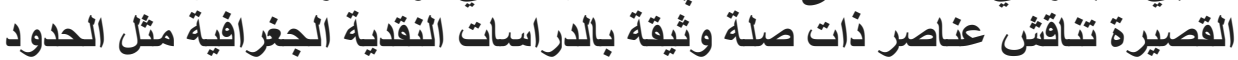

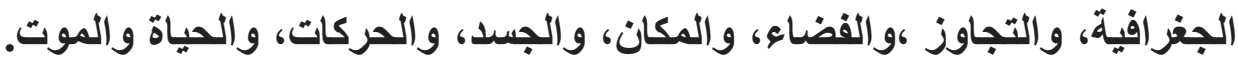

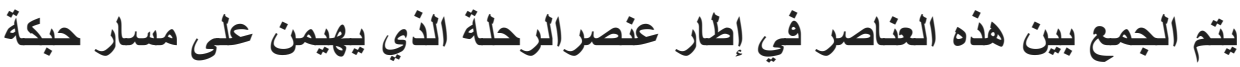




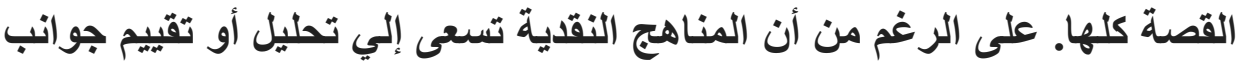

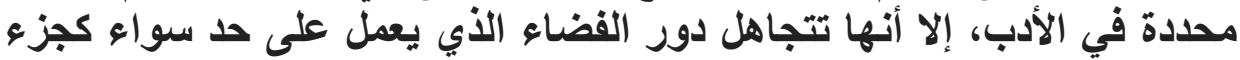

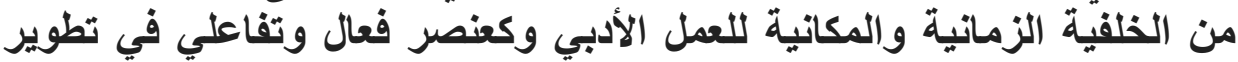

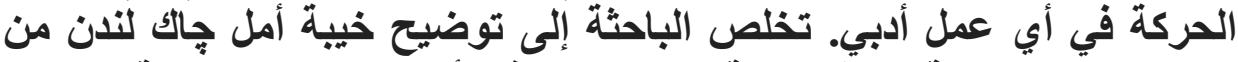

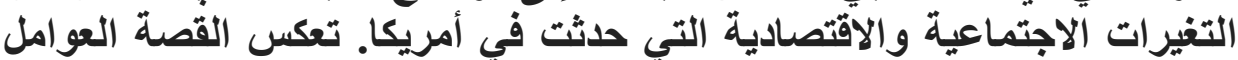
الجغرافية والمعايير الاقتصادية الاحتماعية التي تراجعت بشئية التكل هائل في المكان التي حدثت فيه.

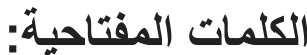
مدخل النقد الأدبي الجغرافي، ما بعد الحداثة،الفضاء، التزوح، عنصر الرحلة،

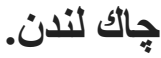

\section{Loneliness and Displacement: A Postmodern Geocritical Reading of Jack London's "To Build A Fire ${ }^{\mathrm{i} "}$}

"To read and to journey are one and the same act" ii (Michel Serres 14) The main objective of this paper is to draw on the findings of geocriticism as an analytical tool to examine the physical setting in London's "To Build A Fire" through defining its fictional and real spaces. It investigates the relationship between the physical space of nature and the mental space of the main protagonist. The paper aims at creating a spatial perspective in a postmodern society fretting from anxiety, loneliness, fragmentation, detachment, alienation and displacement. A spatio-temporal analysis is followed here as the method of research. The paper seeks to apply the approach of geocriticism to Jack London's "To Build A Fire" as this short story discusses elements which are germane to geocritical studies such as geographical boundaries, transgression, space, place, body, movements, life and death. Such elements are brought together within the journey motif, a widespread spatial schema, which 
dominates the course of "To Build A Fire". Though critical approaches tend to investigate or evaluate specific aspects in literature, they ignore the role of space which works both as part of the setting and as an effective and interactive element in the development of action in any literary work.

Though geocriticism is considered a relatively new era of critical investigation, the term "spatial turn" was introduced by Edward Soja in mid-nineties and has recently been receiving increasing scholarly attention in literary studies. While giving a geocritical reading of a written text, one observes the manner in which the geographical landscape is portrayed, to what degree the character and the author exhibit the fictional space, to what degree this may be seen as a reflection of one's understanding of the real space and, how human characters act upon, and react to the environment, and how the characters and author use place and space. A spatial literary study investigates literary representation along with the experience of place and of displacement. It offers a novel tool to reading a literary text that is engaged in a spatial milieu; something which enables new ways of studying literature and culture. A good reader notices that Geocriticism resembles the issues of Ecocriticism. Both critical movements complement one another. Common grounds are mutual between Ecocriticism and Geocriticism; namely, nature, landscape, place and space.

Many geographers and sociologists distinguish between two concepts: place and space. According to Bertrand Westphal, one of the founders of geocriticism, space is a term encircling the universe; "it is oriented toward the infinitely large or reduced to the infinitely small, which is itself infinitely and infinitesimally vast" (4). An area for action and movement, space is regarded as the existing physical environment in which a story takes place. 
Similarly in The Cambridge Dictionary of Philosophy, it is defined as "an extended manifold of several dimensions, where the number of dimensions corresponds to the number of variable magnitudes needed to specify the location in the manifold" (Audi 866-867). Add to this definition the four remarkable dimensions in which all physical objects are situated: height, width, depth and time. On the other hand, "place is a landmark upon which the eye pauses when it surveys a general scene. It is 'a point of rest"' (Westphal 4). It is where the person stops and rests. Simply put, when one becomes familiar with a space, it becomes a place.

Postmodern fiction has great affinity with the concept of space. Postmodernism provides an illustration for understanding social change. It looks at the character's mental mapping in the literary text. In The Condition of Postmodernity, David Harvey indicates that fragmentation, and distraction in the human psyche happen through a change in the way time and space are perceived (301). In "Postmodernism and Space", Michael Foucault emphasizes that "the anxiety of ...[the] era has to do fundamentally with space, no doubt a great deal more than with time. Time probably appears to us only as one of the various distributive operations that are possible for elements that are spread out in space" (qtd. in Murphet 116). Postmodern people live 'more spatial[ly]' than modern people who lived 'more tempotal[ly].'

In his groundbreaking book The Production of Space, Henri Lefebvre, whose brilliant thoughts establish the 'spatial turn,' believes that the postmodern perspective internalizes "an indefinite multitude of spaces [...] [such as] geographical, economic, demographic, sociological, ecological, political, commercial, national, continental, [and] global" (8). He indicates that each one of these previously mentioned spaces may be "contained within the 
next" or piled upon the other (8). Again, what he declares indicates that living in a postmodern era means living more spatially. Speaking about space, one cannot ignore Mikhail Bakhtin's idea of the "chronotope" which integrates time and space. He defines the "chronotope" as "the intrinsic connectedness of temporal and spatial relationships" (84). He goes on writing that these tempo-spatial relationships are artistically expressed in literature" (84). Time becomes artistically visible while space becomes charged and responsive to the movements of time, plot and history (84). Bakhtin's idea of chronotope indicates an abstract space and a static time.

Similarly, in Postmodern Geographies, Edward Soja refutes the view that the collapse of Paris Commune in 1871 signals the triumph of historical over spatial critique in the radical tradition. According to Soja, the overwhelmingly unrivalled historicity is "stripped of its more geographically sensitive variant" (31). He concludes that spatial critique remains deeply inert during the modern era (31). He believes that a postmodern geography "is taking shape [...] reasserting the interpretive significance of space in the historically privileged confines of contemporary critical thought" (Soja 11). At the heart of criticism geography does not display history. In the nineteenth century modern critical consciousness, space was subordinated to time, an indication to the huge timespace compression of the industrial revolution. Foucault affirms that the nineteenth century's great obsession was "history with its themes of development [...], of crisis and cycle, [those] of the ever-accumulating past, with its great preponderance of dead men and the menacing glaciation of the world" (Other Spaces 22).

The early twentieth century witnesses the dominance of temporality over spatiality. Unlike other critics, Foucault uses the history of social and political institutions 
and discourse" (Lodge 196). He contrasts time and space, putting it bluntly in his book Power/ Knowledge: "Space [is] treated as the dead, the fixed, the undialectical, the immobile. Time, on the contrary [is] richness, fecundity, life, dialectic" (Foucault Power 70). Yet, he perceives a reversal of the dominance of temporality over spatiality in late twentieth century due to the anxiety of the era. In his interview with Paul Rabinow, Foucault claims: "Space is fundamental in any form of communal life; space is fundamental in any exercise of power" ("Space" 140). According to Westphal, "once space [is] mastered, subjected to increasingly compression by the development of enhanced communication (material and immaterial), time itself finally [becomes] unhinged, ruptured, and lost" (11).

Though the above detailed discussion shows that time and space are traditional signs of fundamental social transformation and interrelated coordinates in one's daily experience, the researcher argues that Jack London in "To Build A Fire" emphasizes space over time in order to give a spatial interpretation of the real world. This is the core of geocriticism which emerges early in Europe in the works of pioneer French critics such as Henri Lefebvre, Bernard Westphal and in the works of some Americans such as Robert Jr Tally and Edward Soja and fictionalized in the works of Jack London. Geocriticism enables one to feel "free to employ a methodology that allows the space to be seen from new angle, an angle that resituates the entire field" (Westphal 113). According to Terry Eagleton, the narrative task considerably is "[t]o deconstruct [which means]...to reinscribe and resituate meanings, events and objects within broader movements and structures; it is, so to speak, to reverse the imposing tapestry in order to expose in all its unglamorously disheveled tangle the threads constituting the well-heeled image it presents the 
world" (80). In other words, to deconstruct is to dismantle structure which will lead to a new way of conceiving the functions of traditional concepts. Through critical analysis, deconstructing offers new ways of understanding basic concepts.

Geocriticism, as an analytical tool and an interdisciplinary approach, draws attention to the space representations within literary texts. Westphal's ground breaking book lays out a detailed analytical method of it, as Robert Tally has noted, it invites readers to engage in a debate, about the nature and practices of spatial literature studies (3). It enables readers to reflect upon the representation of space and place, both in imaginary universe and in arenas where fiction reality meet. The author's task is to illustrate both real and fictional spaces which serve various purposes depending on the author's desired outcome. It explores literary texts as a means of revealing the rich imaginative textures of real, lived places.

To read the writing of a particular locale, the material setting for social relations, is to read the place itself within the titles of critical studies. It is the way indicated by Michael Serres in his comment on Jules Verne's Hermes: Literature, Science, Philosophy. In a sense, writing and mapping have come to signify the same things. Based on London's extensive travels across the toughly frozen territory of Alaska and Canada during the Klondike Gold Rush at the end of the nineteenth century, London's "To Build A Fire" tells a lot about its Yukon setting. It evokes the Klondike territory most vividly. In his unnerving journey dominating the whole story, the unnamed protagonist is bound to the gold mining camp on a remote fork of Henderson Creek. Endowing space with some imaginative values, London roots his American capitalist culture in the physical world, underlining the sense of place. 
Jack London uses the journey motif, a widespread spatial schema, to structure his story. London is keen on foregrounding space rather than time and on delineating his characters as always in the move. His character types tend to be repetitive. For example, London's "Love of Life,"iii a compelling adventure story, revolves around two unnamed starved gold prospectors wearily walking across the vastly frozen arctic plain of Canada in search for food: "They limp painfully down the bank, and once the foremost of the two men staggered among the roughstrewn rock" (London "Life" par.1). The two men are on the move; they march towards an uncertain fate. Similarly, if one turns to London's earlier one-page version of "To Build A Fire" (1902), one finds a man named Vincent on the move. He builds a fire and survives, yet loses a toe. It ends with a hard learned moral: Never Travel Alone. It starts with a causal reference to time then emphasizes place: "It [is] on a bleak January when the experience [comes] that teaches him respect for the frost [...] He ha[s] left Calumet Camp on the Yukon with a high pack on his back" (Youth Companion 275).

In the same manner, "To Build a Fire" (1908) opens with a causal reference to time and an unnamed man, immediately followed by unmistakable focus on space: "Day has broken cold and gray, exceedingly cold and gray" (London 241). London keeps on repeating the word "cold' for more than twenty five times with a predictable effect to emphasize the extremity of the lethal weather in the Yukon place. The unnamed protagonist "turn[s] aside from the main Yukon trail and climb[s] the high earthbank" (241). He heads to a "trail led eastward through the fat spruce Timberland. It [is] a steep bank". Here is a deliberate emphasis on space. London depends on descriptive writing to establish setting in place and time. From the opening sentence, one notices that the man leaves 
the main trail for one that is "dim and little-travelled", an indication of both his independence and recklessness. The unnamed man starts his story at 9 am with more than nine hours of hike lying between him and the mining camp on Henderson creek. We as readers and critics of literature do not know how long he has been walking or if it is too late for him to go back the way he came or not.

This is a typical Londonian beginning which soon turns back to space after a causal recording of time. London depicts remarkably meticulous details about the physical characteristics of the landscape and surroundings in which his protagonist's extraordinary journey takes place. There is the second mention of the unnamed protagonist who "flings [to have] a look back along the way he ha[s] come" (London 241). The Yukon [lies] a mile wide and [hides] under three feet of ice (241). The protagonist's backward movement is subconsciously known in the act of motion. By shifting from one place to another the man acquires a sense of direction. Here, one can notice that space is given priority over any other element of the story. It is as what Westphal, one of the founders of geocriticism, argues that space is more important than time and geography is more important than history.

Geocriticism, at its heart, attempts to reveal the intrinsic and extrinsic dimensions in man's life through understanding the relationship between space and various fields of experiences. Postmodernist fiction also is interested in "psychological" and "geographical spaces" (McHale 186). The deep changes of the space-time coincide with what takes place in the tumultuous postmodern world. It can orient the individuals to change social sphere by giving them conceptual or imaginary geography. According to Robert Tally in Geocriticism and Classic American Literature, though the American writer's narrative maps function to "make sense and give form to 
the world in a recognizable way" (3), the critic "makes sense of the ways we make sense of the world" (3). Readers are offered a sense of the precariousness of the socioeconomic conditions postmodernism has created. The journey into Canada and Alaska, a multifaceted one, will test these changes and deconstruct many notions.

Since "To Build A Fire" is set in a particular place, The Klondike Territory, London seeks to unravel the distance between fiction and reality on the geographical indices inherent in the story. London contributes to the significance of place by layering a story and a character into its texture. He draws attention to the complexity of the place as an imaginative construct. He keeps giving precise descriptions of the place to emphasize the brutal coldness and the winter landscape of the Northland. The text delineates the overlapping territories of an actual physical geography. It infers the mental mapping of its main character. He goes through a process of discovering himself, his society and the human existence.

The protagonist, a "chechaquo", is a newcomer who undergoes transgression; "a process accompanying movement and motive" (Westphal 45). He transgresses the boundaries of established norms by deciding to take a journey across the Yukon Territory whereby temperature is seventy five degrees below zero without even having a trail companion. He ignores the advice of an Old Timer from Sulphur, a symbol of the Wise Old Man, and travels in the Klondike winter with only a husky dog to accompany him. To reach that destination, the Klondike folks follow either of two ways: Chilkoot or the White Pass Trails to the Yukon River; a major river of North America located in Canada. In this story, the protagonist chooses the harshest choice which is the latter; he is required to bring a supply of food that suffices him one year to prevent both starvation and a lethally cold climate. 
Yet, the problem with the protagonist, according to London's omniscient narrator, is that he is without imagination. Though he is careful enough to look for precarious cracks in the river trail, he is "unreflective". He lacks sociological imagination which is, in the words of Wright Mills, "a quality of mind that will help [the individual] to use information and to develop reason in order to achieve lucid summations of what is going on in the world and of what may be happening within themselves" (5).The man cannot understand his own experience being alone in a deserted space in a deathly cold weather. He is foolishly unconcerned about the deathly cold of the space. London has given many cues of his protagonist's macho self-image. His utter self-confidence and his lack of imagination will prove to be his crucial tragic flaws at the end. The physical space of nature turns out to be severe. He is confronted with a strangely perilous space radically different from his own. He feels anxious and bewildered in this vast space. It is, perhaps, what Robert Tally, one of the field's adherents, would mean by "cartographic anxiety or spatial perplexity" (Spatiality 1).

One of the outcomes of the man's lack of sociological imagination is that he is unable to understand his own experience and, to quote Wright Mills's words, unable to "calculate his own fate by situating himself within his period" (5). That is to say, the individual can recognize his own opportunities in life "only by becoming aware of those of all individuals in his circumstances" (5). The protagonist, here, does not recognize the significance of "fifty degrees below zero" which means more than seventy five odd degrees of frost. His utter confident self-image entices him that he will cope with the rigours of a hard climate. The task of the critical analyst is to recognize and understand the relationship between history and geography and their relations with society. Yet, the 
intellectual journey, here, can only be completed with the joining of geography and biography.

On the complexity of the travel experience, ClaudeLevi Strauss describes it as a displacement in space. A journey occurs in space, in time, and in the social hierarchy (89). To have an adequate representation of any journey, one has to relate these three axes simultaneously. Drawing on London's "To Build A Fire", displacement in space here is a metaphor; it is a projection of the postmodern socioeconomic burdens, of the need for the social difference and meaning through striking it rich by delving in the gold mines. Man's impoverishment, his loss of independence, his estrange- ment from his fellowmen are so many aspects of man's estrangement from his true nature. The rapid economic process in the postmodern era leads to man's alienation. The journey symbolizes the absolute necessity of radical change in the individual's life in his culture. He has to get rid of his familiar assumptions and his self-image.

In Dictionary of Literary Themes and Motifs, the journey is defined as "an estrangement from the protective environment of the familiar in order to discover the newness of oneself and of things. Its psycho-literary space lies in what Gabrielle Roy has called an endless tugging between at homeness and the infinite, in a ceaseless quest for an elsewhere. [...] It is the element of seeking that transforms the banal act of traversing space into an authentic act of travelling [...]. So fundamental is the experience of the journey that the passage from life to death or the progression of the spirit through the various stages of virtue and knowledge are expressed in travel metaphors" (Seigneurit 1293). Man leaves the security and familiarity of the known world for the unknown. Man has to detach himself from his fellowmen. Self-consciousness brings about one's detachment from society. Man becomes self-alienated through his contact with what modernity 
brings; one of its worst outcomes is dehumanizing man. The postmodern unnamed man leaves his familiar surroundings and crosses into a mysterious world.

The unnamed man proceeds along a dangerous path which begins to look perplexingly and confusingly long in the absence of an endpoint in the other direction. This serves to weaken the sense of an overview that London's careful measurement of the topography originally created. Although this short story is seemingly a simple one, it increasingly zigzags and twists as it progresses through alien territory. Jack London himself experiences this journey by heading North as one of the gold seekers, hoping to strike it rich. He spends a time in both Alaska and Canada. He writes about that Yukon trail that winds in Alaska and Canada in "To Build a Fire":

This dark hair-line was the trail-the main trailthat led south five hundred miles to Chilcoot Pass, Dyea, and salt water; and that lead north seventy miles to Dawson, and still on to the north a thousand miles to Nulato, and finally to St. Michael on Bering Sea, a thousand miles and half a thousand more. (London 241-2)

London gives his avid readers the geography of the place. He does break the journey up into a series of cautious and measurable units. He establishes a series of reassuring gestures, giving the names of places and safe spots that the unnamed protagonist will be passing through in his quest. He uses locations to guide his mental hike in the Yukon territory. He relies on perceptual cues to keep track of directions and turns in such a precariously vast space. Such cues are ordered by the nearness of location rather than temporal precedence. Temporality is being suspended here in "To Build A Fire". Names of places and objects give readers a sense of being able to control the world. Yet, this sense of control proves illusory when one comes across 
dark images and mysterious phrases: "an intangible pall" (241), "a subtle gloom" (241), "a far-reaching hair-line trail" (242), "steep bank" (241), "lack of sun"(241), "Icejams" (241),"tremendous cold" (242), and "weirdness of it all" (242).

The path the protagonist undergoes is a deep and complex psychological path. The protagonist comes to abandon the relative standards of measure by which he has adjusted the exchange of provisions. As he progresses in his march along with his dog, he is faced with unmeasured cold entity and unquantifiable snowy landscape. Whenever his sense of progress is checked by depression, he reassures himself that he must perforce adapt. His actions reflect his most hopeful conception of life. Because of its vast stretches of snow, the Klondike space seems alien to him as a newcomer: "[A]s far as the man's eye [can] see, it [is] unbroken white" except for the trail (241). As the landscape becomes increasingly difficult to measure, the journey begins to lose its markers of distance and number. There is no easy way to make it out from there. The cold landscape contains many blind bends, bubbling springs, water-logged creeks, deep crypts, hidden pools and several traps:"[H]e notice[s] the changes in the creek, the curves and bends and timber-jams, and always he sharply note[s] where he place[s] his feet" (245). He keeps moving, trying to connect, disconnect and reconnect the infinite variety of fragmented spaces he goes through during his extraordinary journey.

Since geocriticism, as Robert Tally states in his "Introduction on Geocriticism", looks at, listens to, touches, smells, and tastes space (2), London focuses on the protagonist's sensory organs in his perilous journey in the Yukon place which is recognized by its unique setting and topography. The man's sensory organs and experience such as sight and touch enable him to have their strong 
feeling for space and spatial qualities. The man has never experienced such a cold, that's why he keeps "rubb[ing] his cheek-bones and nose with the back of his mittened hand" (London 245). The moment he stops rubbing, his cheekbones go numb. As he walks, he can feel "the give under his feet and hear the crackle of snow-hidden iceskin" (245). To get his feet wet in such a temperature means both danger and delay, for he will be "forced to stop and build a fire". Though he knows the place only from the outside and from chatting with friends and reading guidebooks, the man looks at the creek-bed and studies it and its banks, deciding that the flow of water comes from the right (246).

London's meticulous description allows the reader to create a mental image of the vast space he describes. He adapts spatial arrangement in his description of objects and events. He depicts actions as they appear to the senses (up, down, left, right, next to, below) .The most basic human experience consists of perceiving oneself as a body located in space. According to Westphal, "space revolves around the body, just as the body is located in space. The body gives the environment a spatiotemporal consistency [...] it confers a measure to the world and tries to give it a rhythm of its own, which can then be scanned in the work of representation" (64). Words like "ahead" and "behind", "back" and "front" organize space using the body as reference. They can also be used as metaphors of time: "ahead" refers to the future while "behind" refers to the past. Yet, rarely does London use such words in this story. He asserts space more than time. Another emphasis on space is the use of sound which dramatizes spatial experience. The unnamed man is amazed when his spittle freezes midair before it ever hits the snow. He hears a sharp explosive crackle that startles him (London 242), an indication that it is colder than fifty below. The human 
senses such as taste, smell, and hearing are not separately able to make one aware of a spacious external world inhabited by objects, but the combined senses of sight and touch shall enhance one's apprehension of the world's spatial and geometrical character.

The man tries to reestablish a new relation with that deathly cold space. His gestures like the simple ability to kick his legs, stretch his arms, "swing along his four-mile gait" (London 246), strike his fingers several "sharp smashes against his leg" (247) and "beat his hand savagely across his chest" (246) are basic to his awareness of space. In a futile attempt to prevent his body from being frozen, the man makes several forward, backward and sideway movements; these movements are unconsciously known in the art of motion. He directly experiences space as having room in which to move. Realizing the creeping numbness up his wet body, he runs furiously, hoping to restore the feeling of his feet and to reach the mining camp.

Due to the man's perseverance, however, he reaches one hundred miles of the way. He acquires the ability to thread his way through this lethal space through visual cues. He is described as both "quick and alert" to his surroundings. He fairly acquires a mental map of the place since a rough image of spatial relations can be learned without deliberate effort. The man knows his starting point, his destination and a scattering of intermediate landmarks. He has a general sense of direction to the mining Camp. He identifies Henderson Creek, one of the landmarks which represents one stage of his journey to the old mining camp. Though it has been frozen and can be used as a trail, it is riddled with dangerously hidden winter springs that never freeze; these springs are beneath a thin layer of river ice. Yet this "rough spot" suggests to him that he is on the right track. He avoids these traps and encourages himself having his lunch. Yet he is startled at 
the speed with which his fingers go numb and is frightened at the extremity of the lethal freezing weather. Recalling the Old Timer advice of the necessity of building fires while travelling in winter, he stops to build one before eating. Reassured after eating by the fire, he goes on his journey with his dog guiding him this time as it has an instinctive sense of direction and spatial skills exceeding the man.

The loneliness of the Yukon territory and the vastness of the cold landscape appear to extend endlessly toward an undefined horizon indicating a vague future. The man reassures himself by alluding to the limitless bounty of resources, food and warmth his companions are preparing in the mining Camp he is heading to in his quest. Here, Jack London enforces his dual role as both a leader and an author in willing his man to keep moving forward through the landscape that repeatedly entices him to lie down in despair. The infinite space hides "alternate layers of water and ice-skin" (245). Whenever he breaks into the ice, he goes on breaking through for a time. Sometimes he gets himself wet to the waist (245). This indicates that the interior landscape of these curves and creeks in the Yukon territory has a sluggishly retarding power that threatens to impede the drive of the plot, and that is more commonly associated with the outer space.

Space is an extended metaphor of what takes place in the postmodern world. In a capitalist society, man's impoverishment, his loss of independence and his estrangement from his fellowmen are prominent features of the age. Space is personified as a man and is given a human attribute which is striking; an indication to the severity of cold in Klondike winter and man's estrangement from his true nature: "The cold of space smote the unprotected tip of the planet, and he, being on that unprotected tip, received the full force of the blow" (London 249). Such a brutal physical space draws attention 
to the futility of the man's attempts to comprehend and to control the world, thus to rescue his life and attain his quest. There is no escape from this lethally harsh condition. Resuming his risky journey, the man falls into an icy river, getting immersed "half-way to the knees" (248). Having his face and toes frostbitten, the man starts to build his second fire to dry his frozen moccasins and his saturated thick socks. The man manages to collect "wisps of dry grass" (249) and stiff twigs and builds a successful fire which is promising with life. Fire here is set in sharp contrast with cold. While fire symbolizes life, cold symbolizes death. The picture of the landscape seems to be quite settled.

Unfortunately, the fire the man sets disturbs the space's solitude by melting the ice on the boughs of the dense trees. The man is faced with an insurmountable obstacle, a power that surpasses his own. Despite the lifeless space surrounding the man, Nature-part of the space - lurks in the background and assumes a disruptive energy. The climactic moment comes when the bough sheds its load of snow on the boughs beneath and the loads descend without warning on the man and extinguishes the wonderful fire. Consequently, the man is painfully shocked. It is as if "he [has] just heard his own sentence of death" (London 251). Here, nature acts as a powerful force within the struggle between the individual and its deterministic conditions. Burning his fingers during his unfinished attempts to build a fire construes tactile space; a sign of the man's awareness of a spacious external world. London lets the man's sensory organs strongly experience spatial qualities.

When the disaster strikes, London gives his readers the man's mental mapping. He lets readers navigate the man's mind: "It [is] ... his mistake [...]. He should have built [the fire] in the open". Then he justifies his mistake, 
saying "it [has] been easier to pull the twigs from the brush and drop them directly on the fire" (251). Again, London has given some cues to the man's macho self-image such as his self-confidence and lack of imagination which prove to be his hubris at the end. At first, he rejects the advice of the experienced Old-Timer. He gradually comes to acknowledge his frailty. He learns essential truths about himself and the nature of human existence. Though he perforce adapts, he feels drowned in a bewildering emptiness. Yet, he evokes an even more compelling image of warmth and comfort in his thoughts.

Although it is fundamentally cold, hunger and physical exhaustion that stops the man from keeping the journey up, the larger context of this short story shows his willingness and perseverance to go ahead endlessly and to reach his defined horizon. The man is on the move in a space of multitudinous mutability. What he yearns for is to reach his awaiting friends in the gold mining camp. The rigours of the journey and the trials he undergoes are indications that the new truths about himself are very difficult to face. He remains blind to his personal weaknesses and limitations as a human being. After the snow blots the fire out, the man must come to terms with death. He experiences the exhaustive cycles of knowledge in the Yukon place during his extraordinary journey. The protagonist finds himself stranded in the deathly cold without guides nor provisions. The notion of having camaraderie is evoked and postponed: "Perhaps the OldTimer on Sulphur Creek [is] right" (London 251). He accursedly contemplates: "If he had only had a trail-mate he would have been in no danger now. The trail-mate could have built the fire" (251). The more the man is in conflict with space, the more inharmonious he is with the whole world. He reaches epiphany; it refers to moments of 
realization when he-at last-acknowledges the accuracy of the advice given to him by the experienced Old-Timer.

During his extraordinarily peril-filled journey, the man gains knowledge, expertise and consciousness. He tries to be inspired by the lethal space around him: the cold sky, the dense trees, the hidden bends and bubbling springs. Spatial contemplation initiates him into the world of epiphany when he is about to meet death. The man, in his despair, battles against his husky dog to survive the harsh and brutal cold space but in vain. He freezes to death before reaching the mining camp due to his unreliable faculties and his faulty judgment. Never before did he experience the Klondike extreme winters, yet the man travels alone on foot without even having a sled. Though the experienced Old-Timer from Sulphur has warned him of the danger that lies ahead and advised him never to travel alone after fifty below zero without a partner who can help him in emergencies, the man's only companion in his risky journey is a husky dog. The wide space invites contemplation. When dying, the man fantasises seeing his friends discovering his frozen body. Then he hears himself admitting his mistake to the Old-Timer from Sulphur. The imaginative appearance of the Old-Timer when the man arrives a dead end is typical of the Wise Old Man. His appearance symbolizes the protagonist's self-realization. The man should not have risked death on the trail during winter.

Closely tied to the rubrics of geocriticism is language since the latter is the medium of spatial representation in literary works. "[C]onveyed by the word, the image and sound, representation is based on a movement (transmission), a relationship (of comparison), and a system of signs (Westphal 75). In "To Build A Fire" London employs a simple terse style second to none except Hemingway. He depends on description, not narration, 
which, according to Marie-Laure Ryan, is "the major discourse strategy for the disclosure of spatial representation"(par. 19). To convey spatial representation, London relies on certain devices such as repetition. London, for instance, repeats a key word-cold- in his short story for more than twenty five times in order to sustain a suspenseful mood. Another literary device is the antithesis between what the protagonist does not know and what the old timer knows along with the dog. The unknown in London's story is represented in the protagonist's ignorance. Ironically, London keeps repeating the sentence "he knew" many a time after the man repeats the same mistake: an indication of the man's macho self-image, determination and courage. At the same time the dog's spatial competence is set in sharp contrast with the man's lack of imagination. The man manages to build a fire twice to keep blood circulation of his body. The fire stands for life while the lethal cold stands for death with which the story ends. He reaches epiphany when he comes to know the unknown.

London's Yukon space is a localized model of fragmented social practices and displaced relationships in the postmodern world. The landscape is large enough to absorb the body of the man. The unfinished aspect of using an infinitive titular "To Build A Fire" conveys the man's unfinished futile attempts to save his life in order to attain his quest. Though to build a fire is a seemingly simple act, it is never fulfilled as a result of the brutal space and the rigours of a hard winter. The space is transformed into a place that human beings can symbolically drown in. This space's lack of boundaries reflects eerily upon the unfathomable cold depth of the Yukon place. London presents a postmodern social space that is flawed and incomplete. Space magnetizes the postmodern man in his 
quest for gold. London's representation of spatiality is filled with tension, conflict and instability.

The spatial representation highlights the peculiarities of the age itself. It addresses the spatial anxieties of the era over the course of the story. People immigrate to Dawson in search for gold mines through the Yukon River which forms the main route for prospectors. During their toughly endangered journey, they experience the exhaustive cycles of knowledge till they meet their fate. The vision of death is palpable since the prospectors do not get prepared for the brutal cold and the eminent dangers they will encounter. The protagonist dies physically and metaphorically. He is intentionally not given a name to represent all postmodern prospectors who are in quest for gold to cope with their capitalist society and to enhance their socio-economic condition. Void of identity, the protagonist symbolizes everyman in the journey of discovering his place in the world; everyman in his quest for richness.

Jack London gives a new picture of life to his readers by combining a represented place of the real world with imaginary spaces. The geographical landscape in "To Build A Fire" roughly emphasizes a life pattern of man's alienation and displacement in a cruel postmodern world. His considerable skill lies in delineating the dislocation within the individual psyche, yet he represents his character as being estranged from the internal spaces of his everyday world. What takes place in this short story is a referent and reflection of the real world. It provides a spatial reinterpretation of the universe. The text expresses man's sense of being lost and alienated in his own world. It shows the effects of the Klondike Gold Rush upon people's way of life.

Not only does London use the journey as the traditional symbol of a quest, but he also employs it to structure his story. He manages to create a setting that contains 
accuracy and familiarity to the real world in an attempt to orient his readers within the narrative frame and to let them create a mental image of the place. Though "To Build A Fire" is not accompanied with a diagram or an illustration, it does comprise some sort of map about the Yukon place. It helps readers to understand the world through the depicted spaces, which is the main function of geocriticism. Spatial representation occupies a privileged position over time in London's short story. The representation of space proves to be a means to trace the social and economic changes of the postmodern era in America. The paradox of the man's journey in the Klondike place lies in that though it is undertaken to be a refuge from the capitalistic age, it proves to be fatal. The death of the unnamed man indicates the death of meaning in the postmodern universe. Framed with the theoretical works of geocritical theorists, the paper deduces London's disillusionment of the socio-economic changes that take place in America. It clarifies essential truths about man and the nature of human existence. London's geographic factors in "To Build A Fire" reflect the dominantly vanishing social economic norms of the place the story is set in. While this paper has focused on spatial representations and their relation to current social and economic conditions in the postmodern society, further studies may bring to light other spatial practices and their relation to current ecological crises. 


\section{Notes}

'This short story was published in 1908 and first appeared in the Century Magazine. In addition to his travels, London depended on pieces of information from a book entitled Three Years in the Klondike, written by Jeremiah Lynch.

ii Michel Serres comments on Vernian extraordinary journey and the experiences of the traveller in his introduction to Hermes: Literature, Science, Philosophy; a good book written by Jules Verne in 1982.

iii. London's "Love of Life" was first published in McClure's Magazine, vol 26,Dec.,1905.

iv. This paper follows MLA Handbook ( $8^{\text {th }}$ ed.)

.https://owl.purdue.edu 


\section{Works Cited}

Audi, Robert(ed.).The Cambridge Dictionary of Philosophy. Cambridge UP, 1999.

Bakhtin, M.M. "Forms of Time and of the Chronotope in the Novel." The DialogicImagination: Four Essays. Translated by Caryl

Emerson and Michael Holquist, Texas UP,1981. pp. 84-137

Eagleton, Terry. Against the Grain: Selected Essays. Verso, 1986.

Foucault, Michael. Power/Knowledge: Selected Interviews and Other Writings 1972-1977. Pantheon, 1980.

---. "Space, Power and Knowledge." Interview with Paul Rabinow. The

Cultural Studies Reader. Edited by Simon During, Routledge, 1993. pp.134-141.

Harvey, David. The Condition of Postmodernity: An Enquiry into the Origin of Cultural Change. Blackwell, 1990.

Lefebvre, Henri. The Production of Space 1974. Translated by Donald Nicholsan Smith. Blackwell, 1984.

Levi-Strauss, Claude. Trisles Tropiques, Translated by John Russell. Hutchinson publishers, 1961.

Lodge, David. Modern Criticism and Theory: A Reader. Longman,1988. London, Jack. "To Build A Fire". The Youth's Companion, V. 76 (May 1902): p. 275

---. Love of Life \& Other Stories. Macmillan,1907.

---. "To Build A Fire" (1908)The Jack London Reader. Philadelphia Running P,1994, pp. 241-258.

McHale, Brian. Postmodernist Fiction. Routledge, 1987

Mills, C. Wright. The Sociological Imagination. Oxford UP, 1959.

Murphet, Julian. "Postmodernism and Space." The Cambridge

Companion to Postmodernism. Edited by Steven Connor,

Cambridge UP, 2004, pp.116-136.

Ryan, Marie-Laure. "Space". The Living Handbook of Narratology.

Edited by Huhn, Peter et al, Hambug UP,2001. Accessed in 21July 2018. http://www.Ihn.Uni-aambung.de/article/space

Seigneurit, Jean Charles. Dictionary of Literary Themes and Motifs. Greenwood, 1988.

Soja, Edward W. Postmodern Geographies: The Reassertion of Space in 
Critical Social Theory. Verso, 1989.

Soja, Edaward. Third Space: Journeys to Los Angles and Other Realand-Imagined Places. Blackwell publishers, 1996.

Tally, Robert T. Geocriticism and Classic American Literature.

Cambridge publications, 2008.

--- (ed.) Geocritical Exploration: Space, Place and Mapping in Literary and Cultural Studies. Palgrave Macmillan, 2011.

---."Introduction: On Geocriticism." Geocritical Exploration: Space, Place and Mapping in Literary and Cultural Studies, Palgrave Macmillan, 2011, pp.1-12.

---. Spatiality (The New Critical Idiom). Routledge, 2013.

--- and Chritine M. Battista (ed.) Ecocriticism and Geocriticism: OverlappingTerritories in Environmental and Spatial Literary Studies. Palgrave Macmillan, 2016.

---.The Routledge Handbook of Literature and Space. Taylor \& Francis, 2017.

Tuan, Yi-Fu. Space and Place: The Perspective of Experience. U of Minnesofa P, 2001. Westphal B. Geocriticism: Real and Fictional Space. Translated by Robert Tally (2011), Palgrove, 2007. 